\title{
Evaluation of Tertiary Institution Students Attitude towards E-Learning in Developing Countries
}

\author{
Fatai Sunmola \\ Department of Computer Science \\ The Federal University of Technology, Akure \\ Ondo State, Nigeria
}

\author{
Akinyokun Oluyomi \\ Department of Computer Science \\ The Federal University of Technology, Akure \\ Ondo State, Nigeria
}

\begin{abstract}
Advancement in the development and application of Digital Technology has immensely contributed to innovative approaches to teaching and learning in tertiary institutions of developed countries. Overtime, inadequacy and abstraction of conventional teaching materials had been a bane of bringing the interest of students to learning as the adoption of digitized method to course management in developing countries is in its infancy still and the success of E-based learning hasdepended on stakeholder's support as well as student adoption of the elearning services. In the wake of the covid-19 pandemic and lockdownthe need for e-learning cannot be overemphasized. In this research, the Blended E-Learning Management System, and the evaluation of students' e-learning readiness in tertiary institutions of Nigeria was appraised. A hundred students from two federal higher institution of learning were selected for the survey using an amended version of the Unified Theory of Acceptance and Use of Technology, (UTAUT) model. The UTAUT model which is one of the comprehensive and robust modelcaptures all the essential elements such as performance expectancy, effort expectancy, social influence, facilitating condition, self-efficacy, attitude toward using technology and anxiety. Data collected were statistically analyzed using both descriptive and qualitative approach. The result suggests that, students in tertiary institutions are readily prepared to adopt e-learning if the facilities are made available.
\end{abstract}

\section{General Terms}

E-Learning, Blended E-Learning Management System

\section{Keywords}

E-Learning, Evaluation, Theory of acceptance and use of technology

\section{INTRODUCTION}

Teaching methodology has evolved overtime stages. There are three (3) distinct stages of its evolution which are: in-campus, distance learning and virtual teaching (e-learning). Traditionally, the oldest method of teaching is to offer lectures face-to-face in classrooms, theatres and laboratories. According to [1] the problem of this method was felt in the last decades of the $20^{\text {th }}$ century. The demand for higher education increased sharply but the traditional universities could not catch up with the pace.

In order to solve this problem, the distance learning methodology was introduced and Open Universities were formed. The main objective was to encourage students to follow the course by using self-paced material usually in written format and in some cases, audio/video materials up to $5 \%$ of the total content. Although this method proved to be cost effective and provided higher education to those who could not attend classrooms due to their working situations or otherwise, nevertheless, was not entirely successful in achieving quality students.By introduction of world-wide-web in Internet and spread of its network to almost any home, distance learning materials have been transformed into web based formats. The new technique was called E-LEARNING and VIRTUAL UNIIVERSITIES have been created using this method of delivery. In e-learning, self-paced courses are offered to students. They can log into the course, read through all of materials and answer some questions online. Then students proceed to the next lesson and so on.

In distance education environments, students have an educational relationship mostly separated in time, place or both. Typically, media are classified in print, audio, video and electronic. Print, as in correspondence education is asynchronous; audio could be synchronous, such as an audio conference, or asynchronous, as an audio tape. Video could be asynchronous (a video tape) or synchronous (a videoconferencing session). On-line learning is mostly asynchronous because the courses and instructions are available round the clock and the students can read and post messages anytime. However, with the increasing use of Virtual Classroom features for learning, some communication online occurs synchronously. In addition, audio and video streaming could be used in both ways, as a live or recorded learning activity.

Although e-learning has been around for decades, it has seen exponential growth in the last years, mainly because of the growth of the Internet. Soon after computers were invented around 1960, psychologists and educators noted the educational potential of computers. Early computer-based instruction development focused on automating relatively simple notions of learning and instruction. Initially, the migration and adaptation of Computer-Based Instruction (CBI), based on mainframes to minicomputer, workstations and personal computers, absorbed much of the energy of researchers and developers. With each succeeding technological innovation, new capabilities and features became available to enhance the technological supported learning process. As the tools matured and personal computer proliferated, costs were dramatically reduced. Recent instructional content incorporate multimedia capabilities and sophisticated authoring features. These computer-based Instructions are characterised by tightly bound instructional content and logic.

E-learning (or electronic learning or eLearning) is a term that encompasses all forms of Technology-Enhanced Learning (TEL) or very specific types of TEL such as online or Webbased learning. Nevertheless, the term does not have a universally accepted definition [2] and there are divides in the e-learning industry about whether a technology-enhanced system can be called e-learning if there is no set pedagogy as some argue e-learning is: "pedagogy empowered by digital 
technology" [3].

\section{LITERATURE REVIEW}

The widespread adoption of Information and Communication Technologies (ICT) especially in the wake covid-19 pandemic and lockdown has enabled the realization of technologically advanced tools for e-learning, on-line collaboration and content delivery [4]; [5]; [6]. Although technology offers impressive possibilities to e-learning other factors such as the underlying pedagogy, educational models, flexibility and cost effectiveness are often overlooked.

\subsection{Education and its Economic Contribution to Knowledge}

Quality education has a high social value in both Singapore and Finland, as evidenced by the fact that their students consistently score among the highest of all students in the world on international assessments [7]. Education also has a high economic value. This is supported by the results of both international micro and macro-economic studies.

According to Robert in his white paper on ICT education reform, and economic growth, states that microeconomic studies focus on the benefit of educational investments to individuals while macroeconomic studies focus on returns to the economy more generally. Microeconomic data from 42 countries found that an average rate of return for an additional year of school was a $9.7 \%$ increase in personal income. A cross-country macroeconomic study found that there was an additional $44 \%$ growth in a country's per capita GDP for each additional average year of attained schooling, a return on investment of $7 \%$. Other studies have found returns that go as high as $12 \%$. The quality of education had an even stronger relationship to growth that did the duration of school participation, the amount learned was more important than the number of years of schooling. Higher test scores of one standard deviation equated to $1 \%$ growth in per capital GDP.

The presence of computer and information technologies in today's organizations has expanded dramatically. [8] decried that some estimates indicated that, since the 1980s, about 50 percent of all new capital investment in organizations has been in information technology. However, [9] observed that, for technologies to improve productivity, users must be willing to accept and used them. One of such technology is online/e-learning technology.
Online learning also known as e-learning is quickly becoming one of the most popular options when it comes to continuing your education. E-learning involves learning materials over the computer, with the help of the internet/intranet/extranet. In an online course, there may be no physical classroom. All assignments, tests, and exams are completed over the computer. The newness of online learning is apparent in the diversity of names given to the phenomenon: Web-based learning, e-learning, and asynchronous learning networks among others, these efforts have focus primarily on offcampus student populations. With the more recent on-campus emphasis, yet another set of labels has appeared, including hybrid learning, blended learning, and mixed-mode instruction. The mere existence of so many names for what is essentially a single concept suggests that no dominant model has yet been accepted as a definition of standard practice [10].

The trend toward conversion from traditional classroom to online courses follows the shift of learning theories from the behaviorist orientation that portrays learning as a primarily passive activity to theorist orientation which emphasize the active, reflective and social nature of learning [11].E-learning includes:Learner-led e-learning, Instructor-led e-learning, Facilitated e-learning, Embedded e-learning, Tele-mentoring and e-coaching,

\section{BLENDED E-LEARNING}

Blended Learning refers to a mixing of different learning environments. The phrase has many specific meanings based upon the context in which it is used. Blended learning gives learners and teachers a potential environment to learn and teach more effectively.

A blended learning approach can combine face-to-face instruction with computer-mediated instruction. It also applies science or IT activities with the assistance of educational technologies using computer, cellular or iPhones, Satellite television channels, videoconferencing and other emerging electronic media. Learners and teachers work together to improve the quality of learning and teaching, the ultimate aim of blended learning being to provide realistic practical opportunities for learners and teachers to make learning independent, useful, sustainable and ever growing [12] 


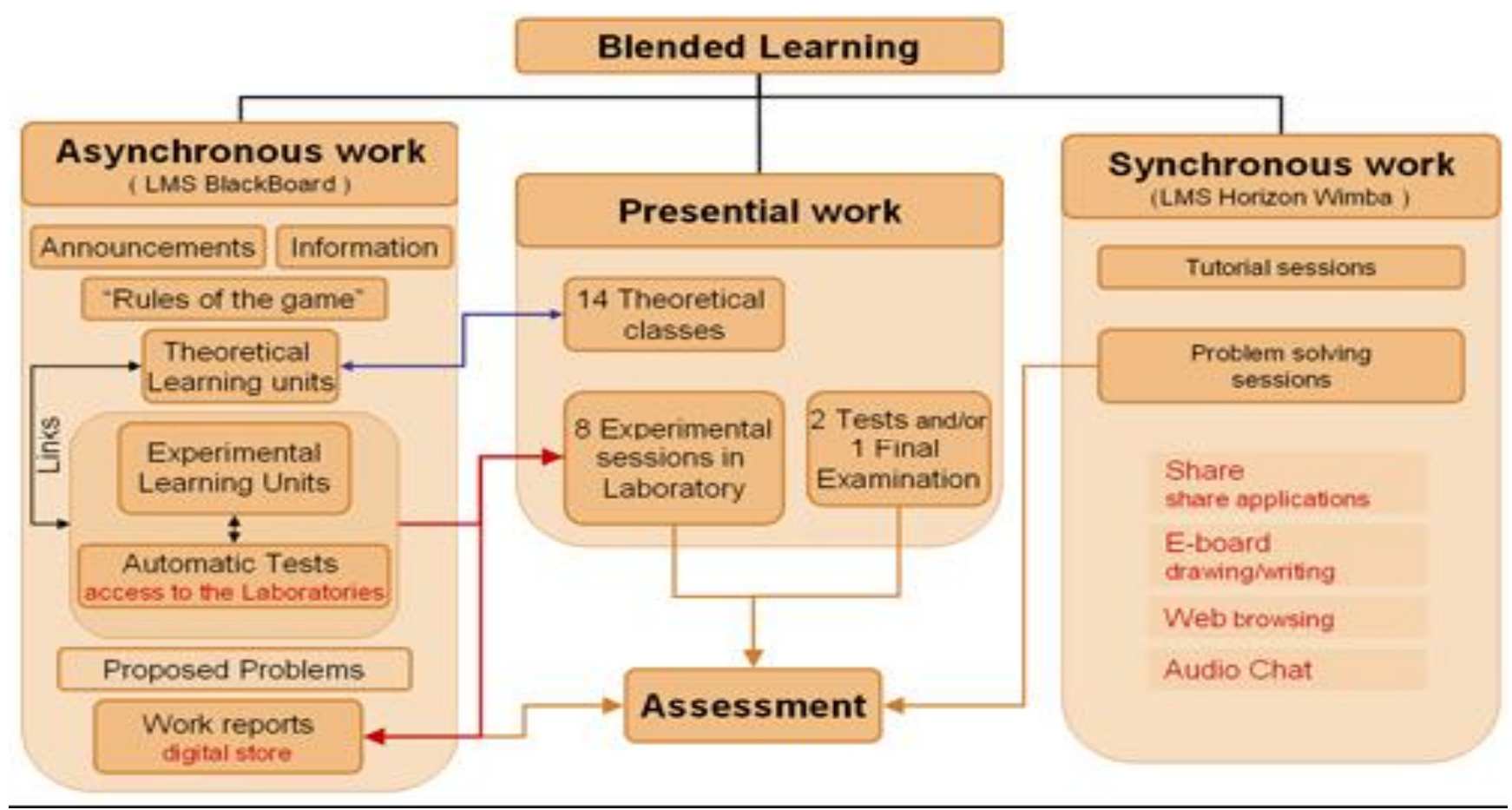

Figure 1: Architectural Framework of the Blended Learning Management System [13]

\section{RESEARCH DESIGN}

The data used for this study were obtained from two important sources as case study - FUTA and NOUN. The field survey, which is a multiple-choiced questionnaire, certified by professionals were structured and administered by the researcher with the help of some FUTA students and colleagues from NOUN, Akure Study Centre. During the survey, the modes of administering the questionnaires were fashioned out. Information collected from the field includes the socio-economic characteristics of respondents, the attitude and behaviour of the students toward e-learning. From this, total numbers of 125 questionnaires were administered, 70 from FUTA students while 55 in NOUN students out of which 100 were recovered.

\subsection{Population and the Study Area}

As mentioned above, this study was carried out among the student of two higher institutions of learning namely: Federal University of Technology, Akure (FUTA) and National Open University of Nigerian (NOUN), Akure Study Centre. FUTA.

\subsection{Sampling Procedure}

FUTA and NOUN were selected as sample for this study because they were established by the federal government with the purpose of providing functional, quality education for young and working-class Nigerians. A systematic random sampling technique was employed in selecting respondents (students) in the study area.

A total numbers of 100 questionnaires were recovered/collected from the 125 administered within the two institutions spread across all schools and departments. The research work employed 82 variables and a sample size of 100 students, giving a rise to 82 variables - by -100 cases matrix. This gives a total of 8200 responses. The figure is perceived to be large enough to ensure reliable research findings in the study areas.

\subsection{Data Collection Procedure}

The collection of data was achieved by engaging FUTA students selected from various schools and departments and some colleagues of the NOUN at degree and postgraduate levels. These trusted students of FUTA and colleagues from NOUN were used for survey, administration and collection of questionnaires.

\subsection{Data Analysis Techniques}

The questionnaires collected through the field survey were collated, sorted-out, coded in accordance to SPSS package numeric coding format. Data coded were entered into MS EXCEL format and validated before copied to SPSS Version 15.0. In the SPSS format, variable names, types, label and values are explicitly defined before the analysis was carried out. The results are presented in the form of tables, percentages, frequency, diagrams and charts where appropriate. The hypotheses set for the study were treated using different statistical techniques.

\subsection{Development of Course Management Sysyem using Moodle}

Moodle is a web-based tool you can access through a web browser. This means that in order to use Moodle, you need a computer with a web browser installed and an Internet connection. You also need to have the web address (called a Uniform Resource Locator, or URL) of a server running Moodle. To meet the above requirements, a Domain Name www.e-itproject.com was registered and paid for one year hosting on the internet for the planning and development of moodle for this research work. The registration and hosting was necessary to allow updating and configuration of themoodle for a whole one year (May 2010 to April 2011). In case your institution supports Moodle, it will have a server with Moodle up and running. You can then get the server address from the system administrator. If you don't have access to a server with Moodle installed, and you like to set up your own, you can download a Moodle package from http://moodle.org/.

ACCESS INTO www.e-itproject.com MOODLE

With your computer connected to internet launch Internet 
Explorer or Internet Mozilla or any other browser you are familiar with. Type the domain name www.eitproject.com/moodle and press return key. Administrator window displays prompting for your username and password as shown in figure 2 below.

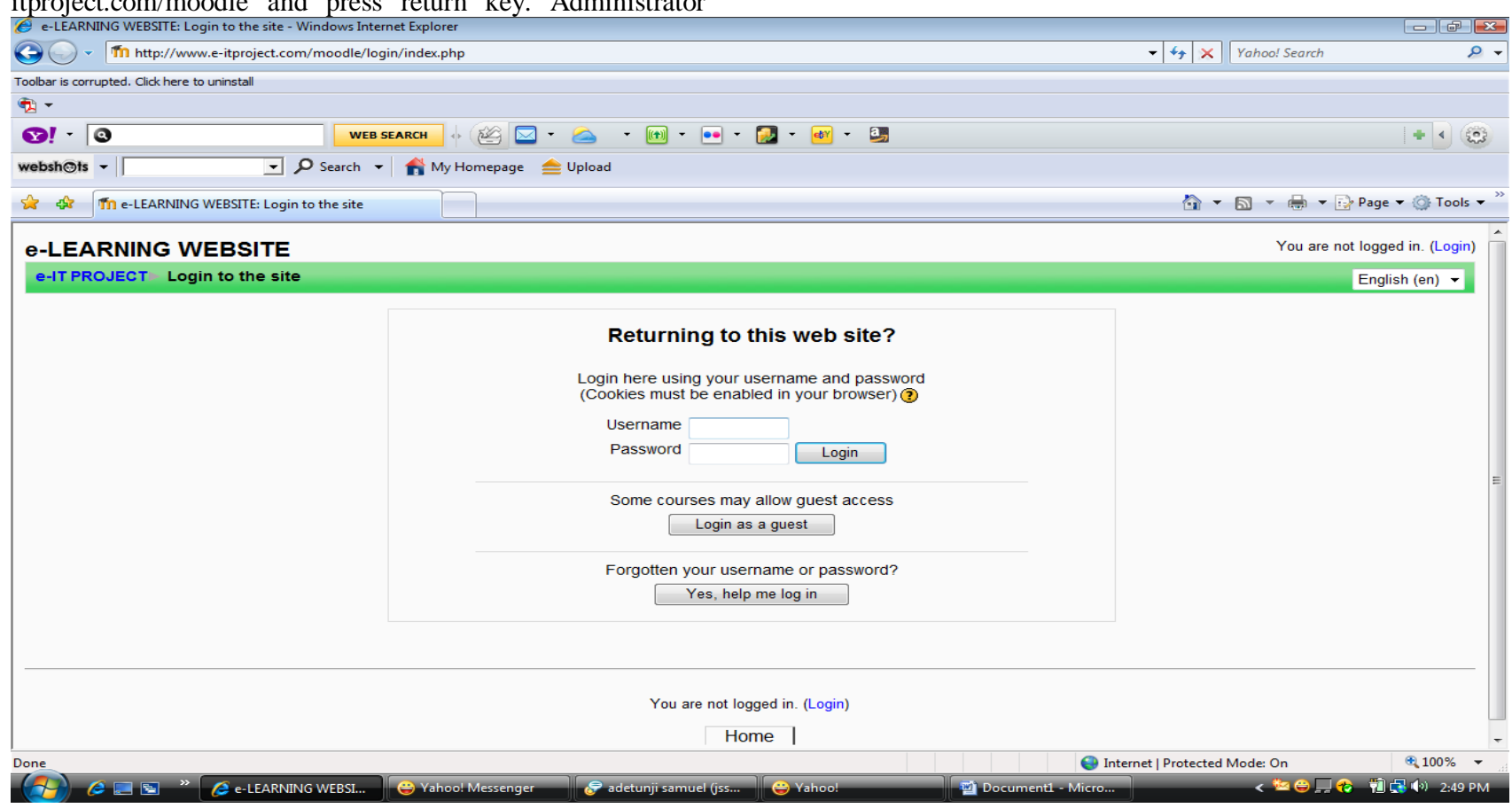

Fig. 2: Login Windows for User Access into the Moodle

\section{RESULTS, ANALYSIS AND FINDINGS}

The report of findings and data analysis for this study is presented in two parts. In the first instance, the situation in terms of socio-economic characteristics of the respondents, their ownership of computer/laptop connected to the internet facilities. Secondly, students attitude toward ICT using e- learning technology were also discussed using relevant techniques. Meanwhile, only 100 questionnaires were possibly retrieved and available for analysis out of 125 administered. This represents $80 \%$ of the expected responses. The distribution in the two institutions involved is shown in Table 1.

Table 1: Frequency Table of the Respondents

\begin{tabular}{|l|r|r|}
\hline Universities & Frequency & Percentage (\%) \\
\hline FUTA & 61 & 61.0 \\
NOUN & 39 & 39.0 \\
Total & 100 & 100.0 \\
\hline
\end{tabular}

\subsection{Socio-Economic Characteristics of Respondents}

vital elements of socio-economic status of the respondents (students) sampled for the study. This is presented in Table 2.

This section presents the survey reports on the socioeconomic status of respondents. In order to appreciate the

Table 2: Age, Sex, Programmes, Schools and Levels of Students

\begin{tabular}{|c|c|c|}
\hline Age Group & Frequency & Percentage $(\%)$ \\
\hline $18-25$ & 40 & 40.0 \\
\hline $26-30$ & 21 & 21.0 \\
\hline $31-35$ & 26 & 26.0 \\
\hline $36-40$ & 1 & 1.0 \\
\hline Above 40 & 12 & 12.0 \\
\hline Total & 100 & 100.0 \\
\hline Sex & Frequency & Percentage $(\%)$ \\
\hline Male & 56 & 56.0 \\
\hline
\end{tabular}




\begin{tabular}{|l|r|r|} 
Female & 44 & 44.0 \\
Total & 100 & 100.0 \\
\hline Programmes & & \\
\hline M.Sc./M.Tech & Frequency & Percentage (\%) \\
PGD & 12 & 2.0 \\
B.Sc/B.Tech & 51 & 12.0 \\
Diploma/Certificate & 22 & 51.0 \\
Others & 13 & 22.0 \\
Total & 100 & 13.0 \\
& & 100.0 \\
\hline Students' Schools & 23 & \\
\hline Engineering & 42 & 23.0 \\
Science & 8 & 42.0 \\
Agriculture & 12 & 8.0 \\
Education & 3 & 12.0 \\
Arts/Business & Frequency & 3.0 \\
Environment & 6 & 6.0 \\
Earth/Mines & 6 & 6.0 \\
Total & 100 & 100.0 \\
\hline
\end{tabular}

Source: Field Survey, 2010.

From Table 2 above, out 100 respondent (students) sampled for survey, age group 18-25 were 40 representing 40\%, 31-35 with 26 representing $26 \%$, while $36-40$ with 1 representing $1 \%$ was the least. In table male were 56 and female 44 representing $56 \%$ and $44 \%$ respectfully. The programmes enrolled for are M.Sc/M.Tech, PGD, B.Sc/B.Tech, Diploma/certificate and others with 2, 12, 51, 22 and 13 respectively. The respondent were also distributed into the following schools, Engineering, Science, Agriculture, Eduction, Arts/Business, Environmental and Earth/Mines with $23 \%, 42 \%, 8 \%, 12 \%, 3 \%, 6 \%$ and $6 \%$ respectively.

The distribution of Desktop computers/Laptops among the students in shown in Fig 3.below with $70 \%$ either has their computer or having directing access to it, while $28 \%$ of the students did not directly has access to it.

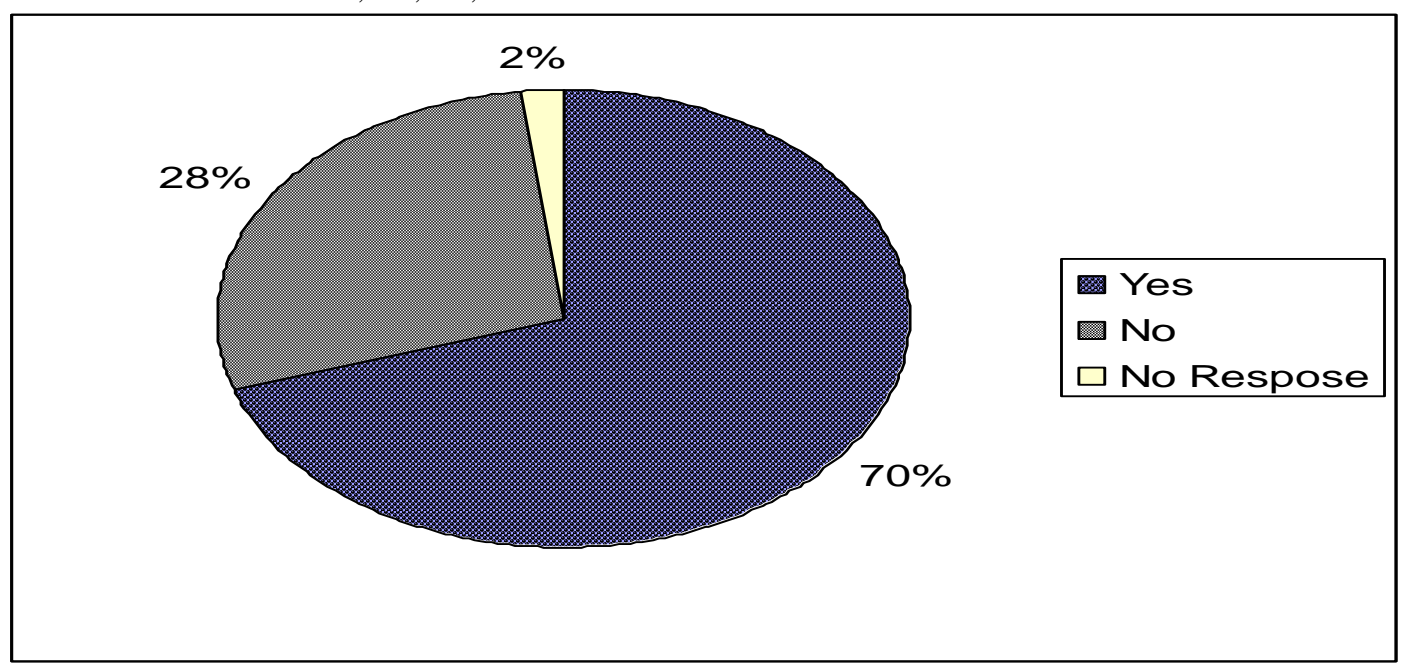

Fig. 3: Students' Ownership of Desktop/Laptop Computers 


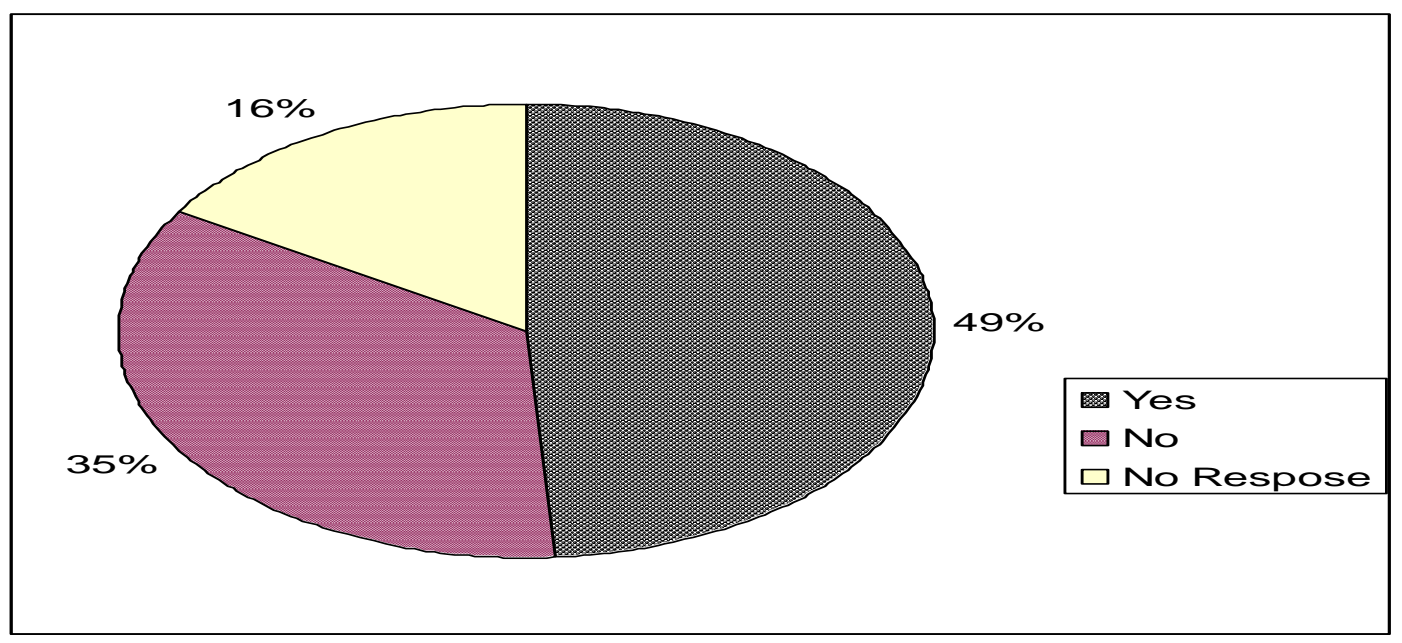

Fig. 4: Internet Connection

In Fig. 4, 49 were connected with internet representing $49 \%$ while $35(39 \%)$ has no interne connection leaving with 16 $(16 \%)$ that did not indicated the connection status.

\subsection{Hypotheses Analysis and Results}

The results of the independent $t$-tests for the significant difference between nature of study and technology access, online skills and relationship, and attitude for the hypotheses 1 to 3 are presented in Table 3 below. The result shows that there is significant difference between part time and full time students in technology access at 0.05 level while online skills and relationship; and attitude towards behaviour are significantly difference at 0.01 level. The independent t-test tests null hypothesis hereby rejected $\left(\mathrm{H}_{\mathrm{o}}\right)$ for all the first three hypotheses.
Table 3: Independent Samples Test of Significant Difference between Part-Time and Full-Time Students

\begin{tabular}{|l|c|r|r|}
\hline \multirow{2}{*}{ VARIABLES } & \multicolumn{3}{|c|}{ t-test for Equality of Means } \\
\cline { 2 - 4 } & Df & $\begin{array}{l}\text { Sig. (2- } \\
\text { tailed) }\end{array}$ & $\begin{array}{c}\text { Std. Error } \\
\text { Difference }\end{array}$ \\
\hline $\begin{array}{l}\text { TECHNOLOGY } \\
\text { ACCESS }\end{array}$ & $34.512 *$ & .019 & .126 \\
\hline $\begin{array}{l}\text { ONLINE SKILLS } \\
\text { AND RELATIONSHIP }\end{array}$ & $85.000 * *$ & .000 & .068 \\
\hline $\begin{array}{l}\text { ATTITUDE TOWARD } \\
\text { BEHAVIOR }\end{array}$ & $20.845^{* *}$ & .004 & .329 \\
\hline
\end{tabular}

Pearson's Product Moment Correlation Co-efficient of R was used to determine the relationship between the type of Programme Enrolled for and Technology Access, Attitude towards Behaiour and online Skills for the hypotheses 4 to 6 is presented in Table 4 below.

Tables 4: Spearman's Correlations Relationship $(\mathrm{N}=100)$

\begin{tabular}{|c|c|c|c|c|c|}
\hline & & $\begin{array}{l}\text { PROGRAMME } \\
\text { ENROLLED } \\
\text { FOR }\end{array}$ & $\begin{array}{c}\text { TECHNOLOGY } \\
\text { ACCESS }\end{array}$ & $\begin{array}{c}\text { ONLINE } \\
\text { SKILLS AND } \\
\text { RELATIONSHIP }\end{array}$ & $\begin{array}{l}\text { ATTITUDE } \\
\text { TOWARD } \\
\text { BEHAVIOR }\end{array}$ \\
\hline $\begin{array}{l}\text { PROGRAMME } \\
\text { ENROLLED } \\
\text { FOR }\end{array}$ & $\begin{array}{l}\text { Pearson } \\
\text { Correlation } \\
\text { Sig. (2-tailed) }\end{array}$ & 1 & & & \\
\hline $\begin{array}{l}\text { TECHNOLOGY } \\
\text { ACCESS }\end{array}$ & $\begin{array}{l}\text { Pearson } \\
\text { Correlation } \\
\text { Sig. (2-tailed) }\end{array}$ & $\begin{array}{l}.079 \\
.435\end{array}$ & 1 & & \\
\hline $\begin{array}{l}\text { ONLINE } \\
\text { SKILLS AND } \\
\text { RELATIONSHIP }\end{array}$ & $\begin{array}{l}\text { Pearson } \\
\text { Correlation } \\
\text { Sig. (2-tailed) }\end{array}$ & $\begin{array}{r}-.593(* *) \\
.000\end{array}$ & $\begin{array}{r}-.006 \\
.953\end{array}$ & 1 & \\
\hline $\begin{array}{l}\text { ATTITUDE } \\
\text { TOWARD } \\
\text { BEHAVIOR }\end{array}$ & $\begin{array}{l}\text { Pearson } \\
\text { Correlation } \\
\text { Sig. (2-tailed) }\end{array}$ & $\begin{array}{r}.412(* *) \\
.000\end{array}$ & $\begin{array}{r}-.201(*) \\
.045\end{array}$ & $\begin{array}{r}-.223(*) \\
.026\end{array}$ & 1 \\
\hline
\end{tabular}


** Correlation is significant at the 0.01 level (2-tailed). * Correlation is significant at the 0.05 level (2-tailed).

1. There is no Significant Correlations (Relationship) between Programme Enrolled for by the students and Technology Access at 0.05 level, null hypothesis hereby accepted $\left(\mathrm{H}_{\mathrm{i}}\right)$ (for the hypothesis 4).

2. There is Significant Correlations (Relationship) between Programme Enrolled for by the students and Online Skills and Relationship at 0.001 level, null hypothesis hereby rejected $\left(\left(\mathrm{H}_{\mathrm{o}}\right)\right.$ (hypothesis 5$)$.

3. There is Significant Correlations (Relationship) between Programme Enrolled for by the students and Attitude Toward Behaviour at 0.001 level, null hypothesis hereby rejected $\left(\left(\mathrm{H}_{\mathrm{o}}\right)\right.$ (in Hypothesis 6).

\subsection{RELIABILITY ANALYSIS OF THE SURVEY INSTRUMENT}

The Reliability Analysis of the survey instrument was carried out using Cronbach's Alpha. Cronbach's Alpha ranges between 0 and 1 , therefore, any value above 0.5 is considered to be reliable. That is, if the value is 0 it means the survey instrument (questionnaire) is not reliable and if the value is 1 means it is perfectly reliable. In Table 5, the Reliability Analysis for the various construct using the Cronbach's Alpha is presented. As in the table, most of the scales in the construct appear to have a good degree of reliability since almost all of the computed statistics is above the value 0.70 .

Table 5: Reliability Analysis Tests for the Construct

\begin{tabular}{|l|l|l|l|}
\hline Constructs & N & Cronbach's Alpha & $\begin{array}{l}\text { Numbers of } \\
\text { Items }\end{array}$ \\
\hline Technology Access & 100 & 0.751 & 6 \\
\hline Online Skills and Relationship & 100 & 0.885 & 8 \\
\hline Motivation & 100 & 0.850 & 3 \\
\hline Internet Discussion & 100 & 0.670 & 5 \\
\hline Benefits of Introducing E-learning & 100 & 0.510 & 8 \\
\hline Foreseen Reason for not willing to use E-learning & 100 & 0.839 & 9 \\
\hline Performance Expectancy & 100 & 0.705 & 5 \\
\hline Effort Expectancy & 100 & 0.838 & 6 \\
\hline Social Influence & 100 & 0.769 & 3 \\
\hline Perceived Behavioural Control & 100 & 0.791 & 5 \\
\hline Attitude Toward Behaviour & 100 & 0.904 & 4 \\
\hline Self Efficiency & 100 & 0.762 & 5 \\
\hline Anxiety & 100 & 0.875 & 4 \\
\hline
\end{tabular}

Table 6 presents the summary of the distributive frequency, percentages, mean and standard deviation statistics of the respondents (students of FUTA and NOUN, Akure) perception with respect to Technological Access. From the table, the minimum mean value of 3.04 suggests strong support for Technology Access. In other words, the students represented in the sampled survey tends to have strong feeling that they have access to at least a fairly new computer, with adequate software to work with and may be connected to the Internet

Table 6: Descriptive Statistics for Technology Access

\begin{tabular}{|l|r|r|r|r|r|r|r|}
\hline Technology Access & $\begin{array}{c}\text { Completely } \\
\text { Disagree }\end{array}$ & $\begin{array}{c}\text { Strongly } \\
\text { Disagree }\end{array}$ & $\begin{array}{c}\text { Not } \\
\text { Sure }\end{array}$ & $\begin{array}{c}\text { Strongly } \\
\text { Agree }\end{array}$ & $\begin{array}{c}\text { Completely } \\
\text { Agree }\end{array}$ & $\begin{array}{c}\text { Mean } \\
\text { Deviation }\end{array}$ \\
\hline $\begin{array}{l}\text { I have access to a computer with } \\
\text { an Internet connection }\end{array}$ & $5(5.0)$ & $18(18.0)$ & $6(6.0)$ & $65(65.0)$ & $6(6.0)$ & 3.49 & 1.020 \\
\hline $\begin{array}{l}\text { I have access to a fairly new } \\
\text { computer }\end{array}$ & $10(10.0)$ & $7(7.0)$ & $6(6.0)$ & $64(64.0)$ & $13(13.0)$ & 3.48 & 1.314 \\
\hline $\begin{array}{l}\text { I own a Desktop/Laptop } \\
\text { Computer }\end{array}$ & $7(7.0)$ & $14(14.0)$ & 0 & $20(20.0)$ & $59(59.0)$ & 4.10 & 1.337 \\
\hline $\begin{array}{l}\text { I own a Printer in addition to my } \\
\text { Desktop/Laptop computer }\end{array}$ & $14(14.0)$ & $35(35.0)$ & 0 & $35(35.0)$ & $16(16.0)$ & 3.04 & 1.385 \\
\hline $\begin{array}{l}\text { I have access to a computer with } \\
\text { adequate software }\end{array}$ & $4(4.0)$ & $7(7.0)$ & $18(18.0)$ & $58(58.0)$ & $13(13.0)$ & 3.69 & .929 \\
\hline $\begin{array}{l}\text { I have the basic skills to operate a } \\
\text { computer }\end{array}$ & 0 & $3(3.0)$ & $8(8.0)$ & $61(61.0)$ & $28(28.0)$ & 4.14 & .682 \\
\hline
\end{tabular}


Table 7 presents the summary of the distributive frequency, percentages, mean and standard deviation statistics of the respondents' perception with respect to online skill relationship. From the table, It was revealing that the responding the students feel strongly with minimum mean value of 3.30, that they have the basic skills to operate a computer, basic skills for finding their ways around the Internet and that they would be comfortable using a computer several times a week for registration, browse and download online.

Table 7: Descriptive Statistics for Online Skills and Relationship

\begin{tabular}{|l|r|r|r|r|r|r|r|}
\hline $\begin{array}{l}\text { ONLINE SKILLS AND } \\
\text { RELATIONSHIP }\end{array}$ & $\begin{array}{c}\text { Completely } \\
\text { Disagree }\end{array}$ & $\begin{array}{c}\text { Strongly } \\
\text { Disagree }\end{array}$ & $\begin{array}{c}\text { Not } \\
\text { Sure }\end{array}$ & $\begin{array}{c}\text { Strongly } \\
\text { Agree }\end{array}$ & $\begin{array}{c}\text { Completely } \\
\text { Agree }\end{array}$ & Mean & $\begin{array}{c}\text { Std. } \\
\text { Deviation }\end{array}$ \\
\hline $\begin{array}{l}\text { I have the basic skills for finding my way } \\
\text { around the Internet }\end{array}$ & 0 & $5(5.0)$ & $4(4.0)$ & $78(78.0)$ & $13(13.0)$ & 3.99 & .611 \\
\hline I can send an email with a file attached & $1(1.0)$ & $34(34.0)$ & $10(10.0)$ & $44(44.0)$ & $11(11.0)$ & 3.30 & 1.087 \\
\hline $\begin{array}{l}\text { I think that I would be comfortable using } \\
\text { a computer several times a week to } \\
\text { participate in a course. }\end{array}$ & 0 & $26(26.0)$ & $9(9.0)$ & $47(47.0)$ & $18(18.0)$ & 3.57 & 1.066 \\
\hline $\begin{array}{l}\text { I think that I would be able to } \\
\text { communicate effectively with others } \\
\text { using online technologies }\end{array}$ & 0 & $3(3.0)$ & $5(5.0)$ & $74(74.0)$ & $18(18.0)$ & 4.07 & .590 \\
\hline $\begin{array}{l}\text { I think that I would be able to express } \\
\text { myself clearly through my writing }\end{array}$ & 0 & 0 & $36(36.0)$ & $49(49.0)$ & $15(15.0)$ & 3.72 & \\
\hline $\begin{array}{l}\text { I think that I would be able to use online } \\
\text { tools (e.g., email, chat) }\end{array}$ & 0 & $3(3.0)$ & $11(11.0)$ & $70(70.0)$ & $16(16.0)$ & 3.99 & .866 \\
\hline $\begin{array}{l}\text { I think that I would be able to schedule } \\
\text { time to provide timely responses to other } \\
\text { students and/or the instructor. }\end{array}$ & 0 & $3(3.0)$ & $39(39.0)$ & $40(40.0)$ & $18(18.0)$ & & \\
\hline $\begin{array}{l}\text { I think that I would be able to ask } \\
\text { questions and make comments in clear } \\
\text { writing. }\end{array}$ & & & & & & 3.73 & .790 \\
\hline
\end{tabular}

Table 8: Descriptive Statistics for Motivation

\begin{tabular}{|c|c|c|c|c|c|c|c|}
\hline MOTIVATION & $\begin{array}{l}\text { Completely } \\
\text { Disagree }\end{array}$ & $\begin{array}{l}\text { Strongly } \\
\text { Disagree }\end{array}$ & $\begin{array}{l}\text { Not } \\
\text { Sure }\end{array}$ & $\begin{array}{l}\text { Strongly } \\
\text { Agree }\end{array}$ & $\begin{array}{c}\text { Completely } \\
\text { Agree }\end{array}$ & Mean & $\begin{array}{c}\text { Std. } \\
\text { Deviation }\end{array}$ \\
\hline $\begin{array}{l}\text { I think that I would be able to remain } \\
\text { motivated even though the instructor is not } \\
\text { online at all times }\end{array}$ & 0 & $3(3.0)$ & $19(19.0)$ & $56(56.0)$ & $22(22.0)$ & 3.97 & .731 \\
\hline $\begin{array}{l}\text { I think that I would be able to complete my } \\
\text { work even when there are online } \\
\text { distractions }\end{array}$ & 0 & $4(4.0)$ & $56(56.0)$ & $20(20.0)$ & $20(20.0)$ & 3.56 & .857 \\
\hline $\begin{array}{l}\text { I think that I would be able to complete my } \\
\text { work even when there are distractions in } \\
\text { my home (e.g., television, children, and } \\
\text { such). }\end{array}$ & 0 & $5(5.0)$ & $40(40.0)$ & $33(33.0)$ & $22(22.0)$ & 3.72 & .866 \\
\hline
\end{tabular}

Table 8 above is the summary of the frequency, percentages, mean and standard deviation statistics of the students (FUTA and NOUN) perception with respect to the motivation for continuous use of e-learning. Results from the table suggest that they strongly agree with minimum mean value 3.56 that they would remain motivated even though e-learning is not available at all times and that they would be able to complete their work schedule even when there are online distractions or distractions.

Table 9: Descriptive Statistics for Internet Discussion

\begin{tabular}{|l|r|r|r|r|r|r|r|}
\hline INTERNET DISCUSSION & $\begin{array}{c}\text { Completely } \\
\text { Disagree }\end{array}$ & $\begin{array}{c}\text { Strongly } \\
\text { Disagree }\end{array}$ & $\begin{array}{c}\text { Not } \\
\text { Sure }\end{array}$ & $\begin{array}{c}\text { Strongly } \\
\text { Agree }\end{array}$ & $\begin{array}{c}\text { Completely } \\
\text { Agree }\end{array}$ & $\begin{array}{c}\text { Std. } \\
\text { Mean }\end{array}$ & \begin{tabular}{c} 
Deviation \\
\hline $\begin{array}{l}\text { I think that I would be able to relate the } \\
\text { content of short video clips (1-3 minutes } \\
\text { typically) to the information I have read } \\
\text { online or in books. }\end{array}$
\end{tabular} \\
\hline $\begin{array}{l}\text { I think that I would be able to take notes } \\
\text { while watching a video on the computer. }\end{array}$ & $4(4.0)$ & 0 & $7(7.0)$ & $79(79.0)$ & $10(10.0)$ & & \\
\hline
\end{tabular}




\begin{tabular}{|l|r|r|r|r|r|r|}
\hline $\begin{array}{l}\text { I think that I would be able to understand } \\
\text { course related information when it's } \\
\text { presented in video formats. }\end{array}$ & $1(1.0)$ & $3(3.0)$ & $15(15.0)$ & $75(75.0)$ & $6(6.0)$ & 3.82 \\
\hline $\begin{array}{l}\text { I think that I would be able to carry on a } \\
\text { conversation with others using the Internet } \\
\text { (e.g., Internet chat, instant messenger). }\end{array}$ & 0 & $6(6.0)$ & $1(1.0)$ & $81(81.0)$ & $12(12.0)$ & .626 \\
\hline $\begin{array}{l}\text { I think that I would be comfortable having } \\
\text { several discussions taking place in the } \\
\text { same online chat even though I may not be } \\
\text { participating in all of them. }\end{array}$ & $4(1.0)$ & $3(3.0)$ & $44(44.0)$ & $30(30.0)$ & $18(18.0)$ & .611 \\
\hline
\end{tabular}

Table 9 above is the summary of the frequency, percentages, mean and standard deviation statistics of the students (FUTA and NOUN) perception with respect to the ability of students to communication on internet, using online browsers, and online chat like yahoo messenger. The results from the table suggest that they strongly agree with minimum mean value

Table 10: Descriptive Statistics for the Benefits of Introducing E-learning

\begin{tabular}{|l|r|r|r|r|r|}
\hline BENEFITS OF INTRODUCING E-LEARNING & \multicolumn{1}{|c|}{ Useful } & Very Useful & Most Useful & Mean & Std. Deviation \\
\hline Ability for students to learn at their own pace & $13(13.0)$ & $25(25.0)$ & $62(62.0)$ & 2.49 & .718 \\
\hline Communication & $35(35.0)$ & $29(29.0)$ & $36(36.0)$ & 2.01 & .847 \\
\hline Encouraging a deeper knowledge of the subject & $18(18.0)$ & $66(66.0)$ & $16(16.0)$ & 1.98 & .586 \\
\hline Helps build on specific skills & $21(21.0)$ & $61(61.0)$ & $18(18.0)$ & 1.97 & .627 \\
\hline Helps target specific weaknesses & $14(14.0)$ & $70(70.0)$ & $16(16.0)$ & 2.02 & .550 \\
\hline Ability to access from anywhere / anytime & $43(43.0)$ & $10(10.0)$ & $47(47.0)$ & 2.04 & .953 \\
\hline Helps to organise and manage programmes & $18(18.0)$ & $26(26.0)$ & $56(56.0)$ & 2.38 & .776 \\
\hline Providing support for distance learning & $8(8.0)$ & $42(42.0)$ & $46(46.0)$ & 2.30 & .785 \\
\hline
\end{tabular}

Table 10 presents the summary of the frequency distribution, percentages, mean and standard deviation statistics of the respondents' perception with respect towhat could be the benefits of introducing e-learning in our institutions of higher
3.56. That if e-learning facilities are readily in place they would make use of it effectively. Like in FUTA where all schools and department are connected to the internet. Even recently, Students' Union Building and Students' Hostel has been connected.

Table 11: Foreseen reasons for you not willing to use E-learning

\begin{tabular}{|l|r|r|r|r|r|r|}
\hline $\begin{array}{l}\text { FORESEEN REASONS FOR NOT WILLING } \\
\text { TO USE E-LEARNING }\end{array}$ & $\begin{array}{c}\text { No } \\
\text { Response }\end{array}$ & Significant & $\begin{array}{c}\text { Very } \\
\text { Significant }\end{array}$ & $\begin{array}{c}\text { Most } \\
\text { Significant }\end{array}$ & $\begin{array}{c}\text { Std. } \\
\text { Mean }\end{array}$ & \multicolumn{1}{c|}{ Deviation } \\
\hline Lack of tutor training & $36(36.0)$ & $30(30.0)$ & $26(26.0)$ & $8(8.0)$ & 1.06 & .973 \\
\hline Reliability of the technology & $8(8.0)$ & $36(36.0)$ & $21(21.0)$ & $35(35.0)$ & 1.83 & 1.006 \\
\hline Lack of tutor support / contact & $8(8.0)$ & $40(40.0)$ & $15(15.0)$ & $37(37.0)$ & 1.81 & 1.032 \\
\hline Difficulties of use of the on-line learning system & $13(13.0)$ & $42(42.0)$ & $12(12.0)$ & $33(33.0)$ & 1.65 & 1.077 \\
\hline Time to prepare/access materials & $10(10.0)$ & $39(39.0)$ & $9(9.0)$ & $42(42.0)$ & 1.83 & 1.092 \\
\hline Additional resources required for use & $11(11.0)$ & $28(28.0)$ & $23(23.0)$ & $38(38.0)$ & 1.88 & 1.047 \\
\hline Management encouragement & $5(5.0)$ & $56(56.0)$ & $29(29.0)$ & $10(10.0)$ & 1.44 & .743 \\
\hline Understanding what is available & $11(11.0)$ & $56(56.0)$ & $7(7.0)$ & $26(26.0)$ & 1.48 & 1.000 \\
\hline Student attitudes & $26(26.0)$ & $11(11.0)$ & $13(13.0)$ & $50(50.0)$ & 1.87 & 1.284 \\
\hline
\end{tabular}

Table 11 presents the summary of the frequency distribution, percentages, mean and standard deviation of the students' perception with respect towhat could be their foreseen reasons for not willing to use e-learning facilities and tools. The trend in the analysis from table shows that their perception on the reason such as Lack of tutor training, Reliability of the learning, their response were overwhelming with minimum mean value of 1.97 and as high as 2.49 . The trend in the analysis revealed that the introduction with greatly improve and prepare our youth for the challenges ahead. technology, Lack of tutor support / contact, Difficulties of use of the on-line learning system, and Time to prepare/access services, Additional resources required for use ICT tools, Management encouragement, Understanding what is available and citizens attitudes are all not very significant and most significant, except others which was not specified. 
Table 12: Descriptive Statistics for Performance Expectancy

\begin{tabular}{|c|c|c|c|c|c|c|c|c|}
\hline $\begin{array}{l}\text { PERFORMANCE } \\
\text { EXPECTANCY }\end{array}$ & $\begin{array}{c}\text { No } \\
\text { Response }\end{array}$ & $\begin{array}{l}\text { Completely } \\
\text { Disagree }\end{array}$ & $\begin{array}{l}\text { Strongly } \\
\text { Disagree }\end{array}$ & $\begin{array}{l}\text { Not } \\
\text { Sure }\end{array}$ & $\begin{array}{l}\text { Strongly } \\
\text { Agree }\end{array}$ & $\begin{array}{c}\text { Completely } \\
\text { Agree }\end{array}$ & Mean & $\begin{array}{c}\text { Std. } \\
\text { Deviation }\end{array}$ \\
\hline $\begin{array}{l}\text { Using the system will enables } \\
\text { me to accomplish my } \\
\text { assignments and study tasks } \\
\text { more quickly }\end{array}$ & $26(26.0)$ & 0 & $3(3.0)$ & 0 & $48(48.0)$ & $23(23.0)$ & 3.13 & 1.947 \\
\hline $\begin{array}{l}\text { Using the system will improve } \\
\text { the quality of my learning. }\end{array}$ & - & $2(2.0)$ & 0 & $30(30.0)$ & $51(51.0)$ & $17(17.0)$ & 3.81 & .787 \\
\hline $\begin{array}{l}\text { Using the system will make it } \\
\text { easier to do my assignment, } \\
\text { learning and study. }\end{array}$ & - & 0 & 0 & 0 & $64(64.0)$ & $36(36.0)$ & 4.36 & .482 \\
\hline $\begin{array}{l}\text { Using the system will enhance } \\
\text { my effectiveness on the } \\
\text { assignment, learning and study. }\end{array}$ & - & 0 & 0 & $3(3.0)$ & $68(68.0)$ & $29(29.0)$ & 4.26 & .505 \\
\hline $\begin{array}{l}\text { Using the system will increase } \\
\text { my productivity interms of } \\
\text { learning. }\end{array}$ & - & $2(2.0)$ & 0 & $3(3.0)$ & $65(65.0)$ & $30(30.0)$ & 4.21 & .686 \\
\hline
\end{tabular}

Table 12 presents the summary of the frequency distribution, percentages, mean and standard deviation of the students' perception on the degree to which using e-learning is perceived as being better than using its traditional old method (performance Expectation). The table shows a minimum mean of 4.13 which translate to the students having the strong feeling that using the e-learning in their universities would enable them to accomplish tasks more quickly, improve their learning which would lead to an increase in performance.

Table 13: Descriptive Statistics for Effort Expectancy

\begin{tabular}{|l|r|r|r|r|r|r|r|}
\hline EFFORT EXPECTANCY & \multicolumn{1}{|c|}{$\begin{array}{c}\text { Completely } \\
\text { Disagree }\end{array}$} & $\begin{array}{c}\text { Strongly } \\
\text { Disagree }\end{array}$ & $\begin{array}{c}\text { Not } \\
\text { Sure }\end{array}$ & $\begin{array}{c}\text { Strongly } \\
\text { Agree }\end{array}$ & $\begin{array}{c}\text { Completely } \\
\text { Agree }\end{array}$ & $\begin{array}{c}\text { Std. } \\
\text { Mean }\end{array}$ \\
Deviation \\
\hline $\begin{array}{l}\text { Learning to operate the system } \\
\text { would be easy for me. }\end{array}$ & 0 & 0 & $12(12.0)$ & $46(46.0)$ & $42(42.0)$ & 4.30 & .674 \\
\hline $\begin{array}{l}\text { I would find it easy to get the } \\
\text { system to do what I want it to do. }\end{array}$ & 0 & 0 & $9(9.0)$ & $77(77.0)$ & $14(14.0)$ & 4.05 & .479 \\
\hline $\begin{array}{l}\text { My interaction with the system } \\
\text { would be clear and understandable }\end{array}$ & 0 & 0 & $10(10.0)$ & $75(75.0)$ & $15(15.0)$ & 4.05 & .500 \\
\hline $\begin{array}{l}\text { I would find the system to be } \\
\text { flexible to interact with. }\end{array}$ & 0 & 0 & $8(8.0)$ & $63(63.0)$ & $26(26.0)$ & 4.06 & .908 \\
\hline $\begin{array}{l}\text { It would be easy for me to become } \\
\text { skillful at using the system. }\end{array}$ & 0 & 0 & $3(3.0)$ & $42(42.0)$ & $52(52.0)$ & 4.37 & .950 \\
\hline I would find the system easy to use. & 0 & $5(5.0)$ & $7(7.0)$ & $19(19.0)$ & $66(66.0)$ & 4.37 & 1.134 \\
\hline
\end{tabular}

Table 13 presents the summary of the frequency distribution, percentages, mean and standard deviation statistics of the students' perception on the degree to which they believes that using a system would be free of effort (effort expectancy). The table reveals that learning to operate the e-learning system would be easy for them and that they would find it easy to get the system do what they want it to do. Also the table reveals that it would be very clear for them to understand the e-learning. They hope the system would be flexible to interact with and they would easily be skillful at using the system and eventually be able to use the system most effectively. The minimum mean value from the table is as high 4.05 .

\section{Table 14: Descriptive Statistics for Social Influence}

\begin{tabular}{|l|r|r|r|r|r|r|r|}
\hline SOCIAL INFLUENCE & $\begin{array}{c}\text { Completely } \\
\text { Disagree }\end{array}$ & $\begin{array}{c}\text { Strongly } \\
\text { Disagree }\end{array}$ & $\begin{array}{c}\text { Not } \\
\text { Sure }\end{array}$ & $\begin{array}{c}\text { Strongly } \\
\text { Agree }\end{array}$ & $\begin{array}{c}\text { Completely } \\
\text { Agree }\end{array}$ & $\begin{array}{c}\text { Mean } \\
\text { Deviation }\end{array}$ \\
\hline $\begin{array}{l}\text { Students in other institutions who use } \\
\text { the system have more prestige than } \\
\text { those who do not. }\end{array}$ & $3(3.0)$ & $1(1.0)$ & $18(18.0)$ & $25(25.0)$ & $47(47.0)$ & 3.94 & 1.391 \\
\hline $\begin{array}{l}\text { Students in other institutions in my } \\
\text { organization who use the system have } \\
\text { a high learning profile. }\end{array}$ & $1(1.0)$ & 0 & $6(6.0)$ & $24(24.0)$ & $61(61.0)$ & 4.20 & 1.421 \\
\hline $\begin{array}{l}\text { Having the system is a status symbol in } \\
\text { my institution. }\end{array}$ & $1(1.0)$ & 0 & $24(24.0)$ & $60(60.0)$ & $12(12.0)$ & 3.73 & .930 \\
\hline
\end{tabular}


Table 14 presents the summary of the frequency distribution, percentages, mean and standard deviation statistics of the students' perception on the degree to which use of an innovation is perceived to enhance one's image or status in one's social system (Social Influence). Basically, majority of the responses strongly agree and complete agree that they will use the system because of the proportion of colleagues who will use the system. Also from the table, it was shown that supervisors (Lecturers) and management of university will be very supportive of the use of the system for students' job and in general, governments are supportive of the use of the system.

Table 15: Descriptive Statistics for Perceived Behavioral Control

\begin{tabular}{|c|c|c|c|c|c|c|c|c|}
\hline $\begin{array}{l}\text { PERCEIVED BEHAVIORAL } \\
\text { CONTROL }\end{array}$ & $\begin{array}{c}\text { No } \\
\text { Response } \\
\end{array}$ & $\begin{array}{l}\text { Completely } \\
\text { Disagree }\end{array}$ & $\begin{array}{l}\text { Strongly } \\
\text { Disagree }\end{array}$ & $\begin{array}{l}\text { Not } \\
\text { Sure }\end{array}$ & $\begin{array}{l}\text { Strongly } \\
\text { Agree }\end{array}$ & $\begin{array}{l}\text { Completely } \\
\text { Agree }\end{array}$ & Mean & $\begin{array}{c}\text { Std. } \\
\text { Deviation }\end{array}$ \\
\hline $\begin{array}{l}\text { I have control over using the } \\
\text { system. }\end{array}$ & $3(3$ & $1(1.0$ & $6(6.0)$ & $1(1.0)$ & $53(53.0)$ & $36(36.0)$ & 4.08 & 1.089 \\
\hline $\begin{array}{l}\text { I have the resources necessary } \\
\text { to use the system. }\end{array}$ & $3(3$ & $2(2.0$ & $18(18.0)$ & $7(7.0)$ & $21(21.0)$ & $49(49.0)$ & 3.88 & 1.395 \\
\hline $\begin{array}{l}\text { I have the knowledge necessary } \\
\text { to use the system. }\end{array}$ & $3(3$ & $3(3.0$ & $3(3.0)$ & $22(22.0)$ & $15(15.0)$ & $54(54.0)$ & 4.05 & 1.282 \\
\hline $\begin{array}{l}\text { Given the resources, } \\
\text { opportunities and knowledge it } \\
\text { takes to use the system, it woul } \\
\text { be easy for me to use the } \\
\text { system. }\end{array}$ & $\begin{array}{l}\text { it } \\
\text { ild }\end{array}$ & $1(1.0$ & $2(2.0)$ & $37(37.0)$ & $30(3.0)$ & $23(23.0)$ & 3.51 & 1.291 \\
\hline $\begin{array}{l}\text { The system is not compatible } \\
\text { with other systems I have ever } \\
\text { used. }\end{array}$ & $4(4$. & $6(6.0$ & $6(6.0)$ & $24(24.0)$ & $10(10.0)$ & $50(50.0)$ & 3.80 & 1.463 \\
\hline \multicolumn{9}{|c|}{$\begin{array}{ll}\text { Table } 15 \text { presented the summary of the frequency distribution, } & \text { conditions. The resulting table suggests mean values of } 4.08, \\
\text { percentages, mean and standard deviation statistics of the } & 3.88,4.05 \text { and } 3.80 \text { which indicates that they have control } \\
\text { students' on the reflects perceptions of internal and external } & \text { over using the system and that the government have the } \\
\text { constraints on behavior and encompasses self efficacy, } & \text { resources and the knowledge necessary to use e-government. } \\
\text { resource facilitating conditions, and technology facilitating } \\
\text { Table 16: Descriptive Statistics for Attitude Behavior }\end{array}$} \\
\hline $\begin{array}{l}\text { ATTITUDE TOWARD } \\
\text { BEHAVIOR }\end{array}$ & $\begin{array}{c}\text { No } \\
\text { Response }\end{array}$ & $\begin{array}{l}\text { Completely } \\
\text { Disagree }\end{array}$ & $\begin{array}{l}\text { Strongly } \\
\text { Disagree }\end{array}$ & $\begin{array}{l}\text { Not } \\
\text { Sure }\end{array}$ & $\begin{array}{l}\text { Strongly } \\
\text { Agree }\end{array}$ & $\begin{array}{l}\text { Completely } \\
\text { Agree }\end{array}$ & Mean & $\begin{array}{c}\text { Std. } \\
\text { Deviation }\end{array}$ \\
\hline $\begin{array}{l}\text { Using the system is a } \\
\text { bad/good idea. }\end{array}$ & $4(4.0)$ & $14(14.0)$ & $13(13.0)$ & $2(2.0)$ & $26(26.0)$ & $41(41.0)$ & 3.55 & 1.635 \\
\hline $\begin{array}{l}\text { Using the system is a } \\
\text { foolish/wise idea. }\end{array}$ & $5(5.0)$ & $13(13.0)$ & $13(13.0)$ & $5(5.0)$ & $47(47.0)$ & $17(17.0)$ & 3.27 & 1.483 \\
\hline $\begin{array}{l}\text { I dislike/like the idea of } \\
\text { using the system. }\end{array}$ & $5(5.0)$ & $3(3.0)$ & $22(22.0)$ & $3(3.0)$ & $53(53.0)$ & $14(14.0)$ & 3.38 & 1.324 \\
\hline $\begin{array}{l}\text { Using the system is } \\
\text { unpleasant/pleasant. }\end{array}$ & $5(5.0)$ & $10(10.0)$ & $38(38.0)$ & $7(7.0)$ & $24(24.0)$ & $16(16.0)$ & 2.83 & 1.450 \\
\hline
\end{tabular}

Table 16 presents the summary of the frequency distribution, percentages, mean and standard deviation statistics of the students' perception on an individual's positive or negative feelings about performing the target behavior (Attitude
Toward Behaviour). The table shows (strongly and completely agree) that the students' will have the system enjoyable, pleasant and is like having fun using the system. Hence they have nice attitude towards using the e-learning.

Table 17: Descriptive Statistics for Self Efficiency

\begin{tabular}{|c|c|c|c|c|c|c|c|}
\hline SELF-EFFICIENCY & $\begin{array}{l}\text { Completely } \\
\text { Disagree }\end{array}$ & $\begin{array}{l}\text { Strongly } \\
\text { Disagree }\end{array}$ & $\begin{array}{l}\text { Not } \\
\text { Sure }\end{array}$ & $\begin{array}{l}\text { Strongly } \\
\text { Agree }\end{array}$ & $\begin{array}{l}\text { Completely } \\
\text { Agree }\end{array}$ & Mean & $\begin{array}{c}\text { Std. } \\
\text { Deviation }\end{array}$ \\
\hline $\begin{array}{l}\text { I could complete my assignment and } \\
\text { study using the system. }\end{array}$ & $2(2.0)$ & $7(7.0)$ & $4(4.0)$ & $50(50.0)$ & $37(37.0)$ & 4.13 & .928 \\
\hline $\begin{array}{l}\text { If there was no one around to tell me } \\
\text { what to do as I go. }\end{array}$ & $3(3.0)$ & $3(3.0)$ & $41(41.0)$ & $26(26.0)$ & $23(23.0)$ & 3.51 & 1.202 \\
\hline $\begin{array}{l}\text { If I could call someone for help if I } \\
\text { got stuck. }\end{array}$ & $12(12.0)$ & $7(7.0)$ & $33(33.0)$ & $39(39.0)$ & $9(9.0)$ & 3.26 & 1.116 \\
\hline $\begin{array}{l}\text { If I had lot of time to complete the } \\
\text { assignment for which the system was } \\
\text { provided. }\end{array}$ & $3(3.0)$ & $7(7.0)$ & $12(12.0)$ & $58(58.0)$ & $20(20.0)$ & 3.85 & .925 \\
\hline $\begin{array}{l}\text { If I had just the built-in help facility } \\
\text { for assistance. }\end{array}$ & $4(4.0)$ & $5(5.0)$ & $16(16.0)$ & $53(53.0)$ & $22(22.0)$ & 3.84 & .961 \\
\hline
\end{tabular}

Table 17 presents the summary of the frequency distribution, percentages, mean and standard deviation statistics of the respondents' perception on the ability to complete their assignment and study using the e-learning. Large percentages of response are in the favour that they could complete their assignment using the system even if there is no one around to tell them what to do. 
Table 18: Descriptive Statistics for Anxiety

\begin{tabular}{|c|c|c|c|c|c|c|c|}
\hline ANXIETY & $\begin{array}{l}\text { Completely } \\
\text { Disagree }\end{array}$ & $\begin{array}{l}\text { Strongly } \\
\text { Disagree }\end{array}$ & $\begin{array}{l}\text { Not } \\
\text { Sure }\end{array}$ & $\begin{array}{l}\text { Strongly } \\
\text { Agree }\end{array}$ & $\begin{array}{l}\text { Completely } \\
\text { Agree }\end{array}$ & Mean & $\begin{array}{c}\text { Std. } \\
\text { Deviation }\end{array}$ \\
\hline $\begin{array}{l}\text { I feel apprehensive about using the } \\
\text { system. }\end{array}$ & $31(31.0)$ & $12(12.0)$ & $30(30.0)$ & $19(19.0)$ & $3(3.0)$ & 2.36 & 1.314 \\
\hline $\begin{array}{l}\text { It scares me to think that I could lose a } \\
\text { lot of information using the system by } \\
\text { hitting the wrong key. }\end{array}$ & $18(18.0)$ & $25(25.0)$ & $12(12.0)$ & $39(39.0)$ & $6(6.0)$ & 2.90 & 1.267 \\
\hline $\begin{array}{l}\text { I hesitate to use the system for fear of } \\
\text { making mistakes I cannot correct. }\end{array}$ & $33(33.0)$ & $23(23.0)$ & $36(36.0)$ & $8(8.0)$ & 0 & 2.19 & .992 \\
\hline $\begin{array}{l}\text { The system is somewhat intimidating } \\
\text { to me. }\end{array}$ & $38(38.0)$ & $43(43.0)$ & $13(13.0)$ & $5(5.0)$ & $1(1.0)$ & 1.88 & .891 \\
\hline
\end{tabular}

The last Table 18 in the series presents the summary of the frequency distribution, percentages, mean and standard deviation statistics of the respondents' perception on individual student becoming anxious when it comes to using the system. Large proportion of the responses were neutral on these issue (not sure) as said they are not sure may be they will I feel apprehensive about using the system, get scares of the thought that they could lose a lot of information using the system by hitting the wrong key or the system may somewhat intimidating them.

\section{DISCUSSION AND RESULTS}

This study attempts to evaluate the attitude of tertiary institution students toward e-learning in regular (Federal University of Technology, Akure) and distant learning (National Open University of Nigeria, Akure Study Centre) Universities. The main areas of concern were limited to assessment of the influence of the types of programme on students' technology access, attitude towards learning and online skills and relationship. It also extended to revealing the effect of mode of study. However, important issues were raised from the results and they provided clear insight into the implementation and adoption of e-learning in Tertiary education.

As presented in Table 2 it was observed that online skills acquisition and utilization are mostly appreciated by the young people. This may not be unconnected with the facts that many of the elderly people who were not opportuned to gain access to the technology in their early days found it difficult to acquire the skills and most times, their conservative attitudes towards the old styles and perhaps nonreadiness to adopt new technology may be preventing them.

The results revealed that there was no relationship between the programme students enrolled for and their access to technology. In Table 3, Independent t-test result shows that there is significant difference between part time and full time students in technology access at 0.05 level while online skills and relationship; and attitude towards behaviour are significantly difference at 0.01 level. This further established that computer users' prior experience with the technology plays a significant role in facilitating their attitude and quest for the technology in general [14]; [15]; and [16]. Meanwhile, [17] opined that the greater amount of experience users have with technology, the higher the levels of users' satisfaction in learning to use new technology. In essence, access to technology and the level of satisfaction derived from the use of the technology are not dictated by the programme undertaken by the users.

Conversely, the present findings in Table 4 of correlation analysis revealed that there was a weak and negative relationship between technology access and attitude toward behavior $(\mathrm{R}=-0.201)$ at 0.045 level of significance. The programme enrolled for also have a high influence on the rate of acquisition of online skills and behaviour.

On the basis of mode of study, it is considerably clear from this present study that the mode of study has a great influence on students' technology access, online skills acquisition and attitude toward behaviour. This may also be related to the differences in the implementation level of the technology for the two mode of study. It must however be stated that parttime students are most times occupied by other activities that may distract them from learning new technology prove more beneficial to them as they have reduced number of contact period with lecturers.

This study focuses on student perceptions by applying the Unified Theory of Acceptance and Use of Technology (UTAUT) model. Many Universities have or are planning on instituting course management software. To this end, it is important to learn its perceived usefulness from the student perspective. By better understanding these perceptions, the results of this study may help Colleges and Universities make better investment decisions and assist instructors in using this technology more effectively. Moreover, it can help course management software designers improve the learning tools to obtain high level satisfaction in the learning environment.

Based on the data collected and an evaluation of several Course Management Systems (CMS); and with the positive assessment of Moodle during the extensive evaluation conducted over the past year, it is strongly recommended that Moodle be chosen as the supported CMS.Moodle has gained a significant amount of support within the higher education community, and corporations are beginning to use it as well. In addition to supporting the use of "traditional" online content and activities in an intuitive, effective fashion, Moodle also offers a wide array of features to support innovative pedagogical techniques. In particular, Moodle excels at providing student-centered, active learning activities. Moodle application could be installed on a server (Moodle Server) to provide prototyping courses with an environment to begin this evaluation process. The server preferably should be housed in the ICT Centre before final decision is be taken on it adoption. 


\subsection{SUMMARY OF FINDINGS}

This survey has established the view perspectives of the respondents (students of FUTA and NOUN, Akure) on the use of e-learning systems in our higher instructions. The results suggest that there are good logistics of implementation but the services are far from reach. Though they admitted that this innovation will enhance their capacity in term of learning, make them more effective and efficient in performance. Quality will improve, cost will drastically reduce and more importantly the huge papers experience in the higher institutions will reduce hence creating a good learning environment.

\subsection{CONCLUSION AND RECOMMENDATION}

By implication, the survey presented in no small measure the perceptions of students in the use of e-learning and its facilities. What is left now is how to make up for the area of weakness as revealed in the study. Lack of inadequate training/tutor was identified as one of the problems militating against the use of e-learning, high cost of the equipment, in accessibility of students to computer/laptop, internet is still very expensive to hook unto. The willingness is there, but the infrastructure is grossly inadequate for the students. There should be a directive compelling all universities personnel to be highly computer literate, this they will transfer to their students.

Taken together, the results bring to the fore the necessity of interventions in the areas of capacity building, proficiency enhancement and infrastructural provision. Also of particular note is the need for regular supply of electricity which is a necessary amenity. Without this, further impediments and backwardness may set-in to the country's education and economic development. E-learning initiatives are not likely to thrives nor achieve optimal results expected if the government under the umbrella of ministry of education did not put in place detailed policy on the use and procurement of ICT infrastructures and supporting equipment in our tertiary's institutions with regular and constant supply of electricity. No electricity no ICT. Also deliberate efforts must be made by institutions to ensure that their personnel (Lecturers, Technologists, Administrative and Technical) develop capacities in the deployment of ICTs in their job functions. There is an inevitable need for training in e-learning pedagogies. This can be achieved through regular and inservice education programmes. All the personnel involved should be encouraged by regular disbursement of allowances and provision of a laptop with internet connection.

Philanthropists, multinational companies, parents and all stakeholders should be encouraged and motivated to supplement the financial burden of development in pursuing computer education and other information and communication facilities. This will contribute and improve the quality of education and help building the nation and her economy.

\section{REFERENCES}

[1] Dorie H. (2002); Blended e-Learning, A background to Blended e-Learning 2002. http://www.kolieh.com/blended.htm

[2] Dublin, L. (2003); If You Only Look Under the Street Lamps. Or Nine e-Learning Myths. The eLearning Developers' Journal, 1-7.

[3] Nichols, M. (2008); E-Learning in context. E-Primer Series
[4] Pittinsky, M.S. (2002); The Wired Tower. Perspectives on the Impact of the Internet on Higher Education. Financial Times/Prince Hall.

[5] Bates, A.W. (2000); Managing Technological Changes. Sam Francisco: Jossey Bass.

[6] Tadesse, S., \&Muluye, W. (2020). The Impact of COVID-19 Pandemic on Education System in Developing Countries: A Review. Open Journal of Social Sciences, 8 , 159-170. https://doi.org/10.4236/jss.2020.810011

[7] Robert, W. (2005); Instructional Technology \& Theory: A Look at Past, Present \& Future Trends, Spring/Summer 2005 - Connect: Information Technology at NYU. whelan_it_history.pd

[8] Westland, J. C., and Clark, T. H. K. (2000); Commerce: Theory and Case Studies, MIT Press, Cambridge, MA, William Horton.

[9] Viswanath, V., Michael, G. M., Gordon B. D. and Fred D. D. (2003); User Acceptance of Information Technology: Towards a Unified View1, MIS Quarterly Vol. 27 No. 3, pp. 425-478/September 2003

[10] Charles G., (2006); "Blended Learning Systems: Definition, Current Trends, and Future Directions", in Handbook of Blended Learning: Global Perspectives, Local Designs, Pfeiffer Publishing, San Francisco, USA,2006.http://www.uab.edu/it/instructional/technolog $\mathrm{y} / \mathrm{docs} / \mathrm{blended}$ _learning_systems.pdf

[11] Barbara A. L., Virginia M. M., Shirley D., Catherine E., Thomas J., Elizabeth T., Sharon W., and Jason W. (2005); Learning Management Systems Comparison, Proceedings of the 2005 Informing Science and IT Education Joint Conference, Flagstaff, Arizona, USA

[12] Graham, C. R. (2005); "Blended learning systems: Definition, current trends, and future directions.". in Bonk, C. J.; Graham, C. R..Handbook of blended learning: Global perspectives, local designs. San Francisco, CA: Pfeiffer. pp. 3-21.

[13] Silvia, Di M., António, M., Páulo R. and Maneira, M.J.P., (2009); Blended-learning in Science and Technology. A Collaborative Project-Based Course in Experimental Physics e-Learning Papers • www.elearningpapers.eu No 16 • September 2009 • ISSN $1887-1542$

[14] Wober, K. and Gretzel, U. (2000). Tourism managers' adoption of marketing decision support systems. Journal of Travel Research, 39(2), 172-182.

[15] Stoel, L. and Lee, K. H. (2003). Modeling the effect of experience on student acceptance of Web-based courseware. Internet Research, 13(5), 364-374.

[16] Martins, L. L. and Kellermanns, F. W. (2004); A model of business school students' acceptance of a web-based course management system. Academy of Management Learning \& Education, 3(1), 7-39.

[17] Volery, T. and Lord, D. (2000). Critical success factors in online education. The International Journal of Education Management, 14(5), 216-223. 


\section{APPENDIX THE ASSEMENT OF THE ATTITUDE OF TERTIARY INSTITUTION STUDENTS TOWARDS E-LEARNING IN NIGERIA SURVEY QUESTIONNAIRE}

Dear Respondent.

Information and Communication Technology (ICT) in education continues to generate interest and discussion amongst scholars, educators, and students. Most research on e-Learning has focused on the perceptions of students. This study set to determines the level of awareness, readiness, acceptability and adoption of blended learning system for the full-time and part-time programmes in Higher learning institution in Nigeria. Your response is therefore an important aspect for decision making for all stakeholders in the Higher learning system. The information supplied in this questionnaire will therefore be treated in the strictest confidence as shall be used for academic purposes only.

Thank you.

\section{Part One: Demographics}

1. Name of the respondent:

2. Institution of study:

(Please tick in the box)

3. Age: Below 18( ) 18-25( ) 26-30( ) 31-35( ) 36-40( ) Above $40($ )

4. Gender: Male ( ) Female ( )

5. Type of programme enrolled for: M.Sc/M.Tech( ) PGD( ) B.Sc/B.Tech( ) Diploma/Certificate( ) Others( ).

6. Your School/Faculty: Engineering ( ) Sciences ( ) Agriculture ( ) Education ( ) Arts/Business ( ) Environmental ( ) Earth/Mines ( ).

7. Your present level in the University: 100 Level ( ) 200 Level ( ) 300 Level ( ) 400 Level ( ） 500 Level ( ) 600 level ( ) 700 Level ( )

8. Nature of your study: Part Time ( ) Full Time ( )

9. Do you own a Laptop/Desktop Computer: Yes ( ) No ( )

10. If Yes, is your Laptop/Desktop connected to Internet: Yes ( ) No ( )

Below are statements requiring your view on of Blended Learning Management System? Please tick in the box that best reflects your feelings $(\sqrt{ })$

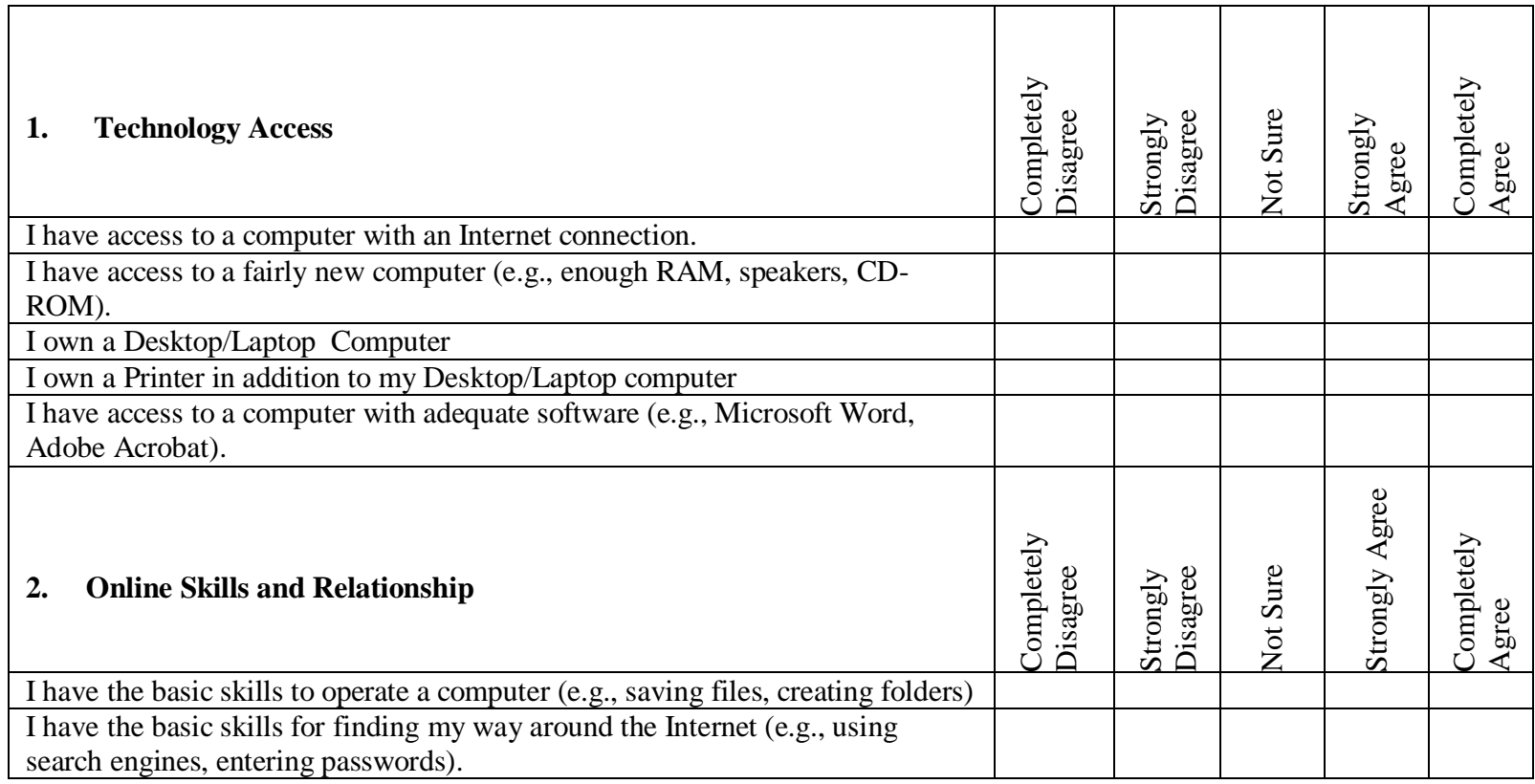


I can send an email with a file attached.

I think that I would be comfortable using a computer several times a week to participate in a course.

I think that I would be able to communicate effectively with others using online technologies (e.g., email, chat).

I think that I would be able to express myself clearly through my writing (e.g., mood, emotions, and humor).

I think that I would be able to use online tools (e.g., email, chat) to work on assignments with students.

I think that I would be able to schedule time to provide timely responses to other students and/or the instructor.

I think that I would be able to ask questions and make comments in clear writing.

\section{Motivation}

I think that I would be able to remain motivated even though the instructor is not online at all times

I think that I would be able to complete my work even when there are online distractions (e.g., friends sending emails or Websites to surf)

I think that I would be able to complete my work even when there are distractions in my home (e.g., television, children, and such).

\section{Internet Discussion}

I think that I would be able to relate the content of short video clips (1-3 minutes typically) to the information I have read online or in books.

I think that I would be able to take notes while watching a video on the computer.

I think that I would be able to understand course related information when it's presented in video formats.

I think that I would be able to carry on a conversation with others using the Internet (e.g., Internet chat, instant messenger).

I think that I would be comfortable having several discussions taking place in

the same online chat even though I may not be participating in all of them.

\begin{tabular}{|l|l|l|l|l|l|}
\hline & & & & & \\
\hline & & & & & \\
\hline & & & & & \\
\hline
\end{tabular}

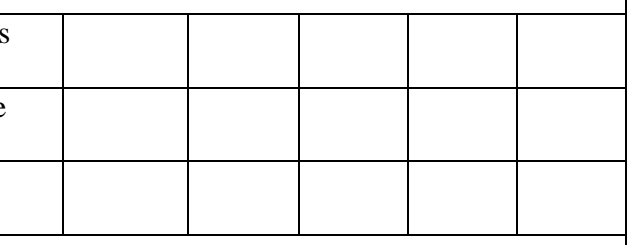

\begin{tabular}{|l|l|l|l|l|l|} 
& & & & & \\
\hline & & & & & \\
\hline the & & & & & \\
\hline
\end{tabular}

\section{On the use of E-learning Management System}

\section{What do you feel are the greatest benefits for introducing e-learning?}

Ability for students to learn at their own pace

Communication

Encouraging a deeper knowledge of the subject

Helps build on specific skills

Helps target specific weaknesses

Ability to access from anywhere / anytime

Helps to organise and manage programmes

Providing support for distance learning

Other (Please specify)

\begin{tabular}{|c|c|c|}
\hline 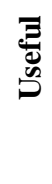 & 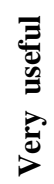 & 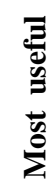 \\
\hline & & \\
\hline & & \\
\hline & & \\
\hline & & \\
\hline & & \\
\hline & & \\
\hline & & \\
\hline & & \\
\hline & & \\
\hline
\end{tabular}

6. What could be your foreseen reasons for you not willing to use e-learning tools?

Lack of tutor training

Reliability of the technology

Lack of tutor support / contact

Difficulties of use of the on-line learning system

Time to prepare/access materials

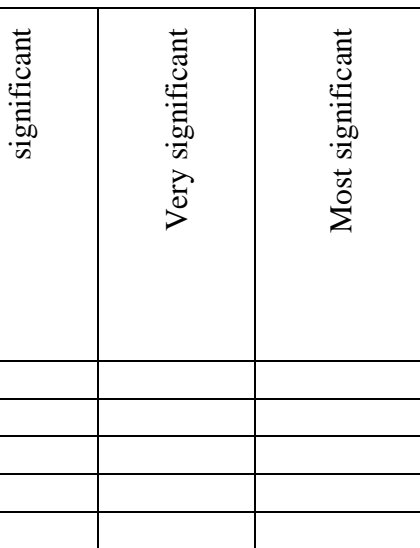




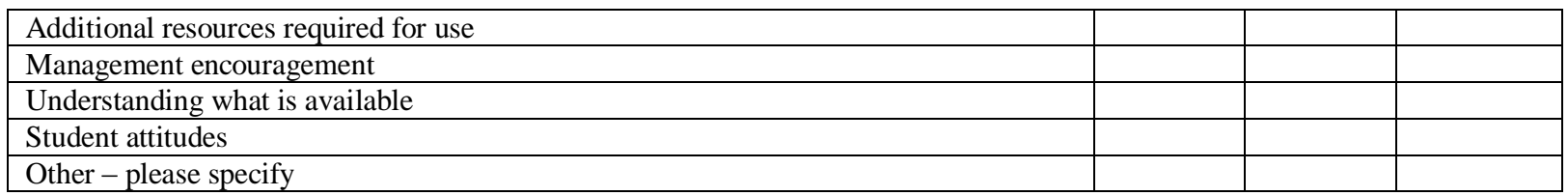

\section{Questions are based on of the modified UTAUT Constructs}

\begin{tabular}{|c|c|c|c|c|c|}
\hline $\begin{array}{l}\text { Performance Expectancy: The degree to which using an innovation is } \\
\text { perceived as being better than using its precursor }\end{array}$ & 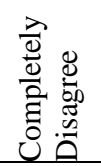 & 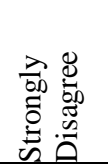 & $\begin{array}{l}0 \\
\vdots \\
\tilde{Z} \\
0 \\
Z\end{array}$ & 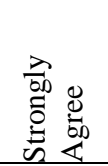 & 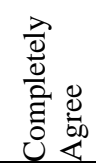 \\
\hline \multicolumn{6}{|l|}{$\begin{array}{l}\text { Using the system will enables me to accomplish my assignments and study } \\
\text { tasks more quickly }\end{array}$} \\
\hline \multicolumn{6}{|l|}{ Using the system will improve the quality of my learning. } \\
\hline \multicolumn{6}{|l|}{$\begin{array}{l}\text { Using the system will make it easier to do my assignment, learning and } \\
\text { study. }\end{array}$} \\
\hline \multicolumn{6}{|l|}{$\begin{array}{l}\text { Using the system will enhance my effectiveness on the assignment, learning } \\
\text { and study. }\end{array}$} \\
\hline \multicolumn{6}{|l|}{ Using the system will increase my productivity interms of learning. } \\
\hline \multicolumn{6}{|c|}{ Effort Expectancy: The degree to which a person believes that using a system would be free of effort } \\
\hline \multicolumn{6}{|c|}{\begin{tabular}{|l|l|l|l|} 
Learning to operate the system would be easy for me. & & & \\
\end{tabular}} \\
\hline \multicolumn{6}{|l|}{ I would find it easy to get the system to do what I want it to do. } \\
\hline \multicolumn{6}{|l|}{ My interaction with the system would be clear and understandable } \\
\hline \multicolumn{6}{|l|}{ I would find the system to be flexible to interact with. } \\
\hline \multicolumn{6}{|l|}{ It would be easy for me to become skillful at using the system. } \\
\hline \multicolumn{6}{|l|}{ I would find the system easy to use. } \\
\hline \multicolumn{6}{|c|}{$\begin{array}{l}\text { Social Influence: The degree to which use of an innovation is perceived to enhance one's image or status in one's social } \\
\text { system. }\end{array}$} \\
\hline \multicolumn{6}{|l|}{$\begin{array}{l}\text { Students in other institutions who use the system have more prestige than } \\
\text { those who do not. }\end{array}$} \\
\hline \multicolumn{6}{|l|}{$\begin{array}{l}\text { Students in other institutions in my organization who use the system have a } \\
\text { high learning profile. }\end{array}$} \\
\hline Having the system is a status symbol in my institution. & & & & & \\
\hline
\end{tabular}


Perceived Behavioral Control: Reflects perceptions of internal and external constraints on behavior and encompasses self efficacy, resource facilitating conditions, and technology facilitating conditions.

I have control over using the system.

I have the resources necessary to use the system.

I have the knowledge necessary to use the system.

Given the resources, opportunities and knowledge it takes to use the system,

it would be easy for me to use the system.

The system is not compatible with other systems I have ever used.

Attitude Toward Behavior: An individual's positive or negative feelings about performing the target behavior.

Using the system is a bad/good idea.

Using the system is a foolish/wise idea.

I dislike/like the idea of using the system.

Using the system is unpleasant/pleasant.

Self-efficacy: Confidence of individual about his ability to use the system

I could complete my assignment and study using the system.

If there was no one around to tell me what to do as I go.

If I could call someone for help if I got stuck.

If I had lot of time to complete the assignment for which the system was provided.

If I had just the built-in help facility for assistance.

Anxiety : An individual becomes anxious when it comes to using the system

I feel apprehensive about using the system.

It scares me to think that I could lose a lot of information using the system

by hitting the wrong key.

I hesitate to use the system for fear of making mistakes I cannot correct.

The system is somewhat intimidating to me. 